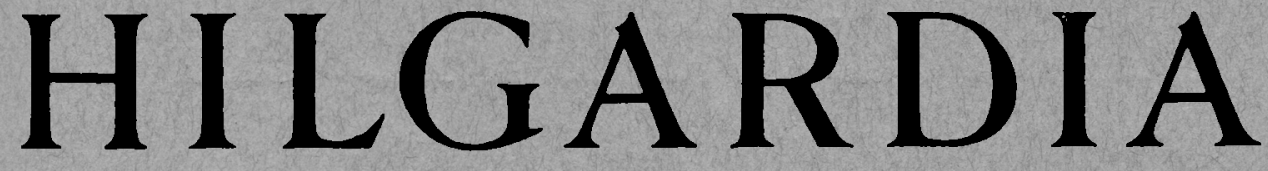

A Journal of Agricultural Science Published by

the California Agricultural Experiment Station

\title{
ON THE SOIL CHEMISTRY OF RADIO-STRONTIUM
}

\author{
R. K. SCHULZ, ROY OVERSTREET, \\ and K. L. BABCOCK
}


The advent of radioactive fallout has stimulated interest in the soil chemistry of radio-strontium. In the present research, the chemical behavior of added $\mathrm{Sr} 85$ in 26 California soils was studied. On the basis of the results of various extraction procedures with ammonium acetate and calcium chloride, it is concluded that added radio-strontium is retained in the water soluble and exchangeable forms. Therefore, barring long-term fixation effects, it is largely available to plants. 


\section{II $\mathrm{I} A \mathrm{R} D$ \\ the California Agricultural Experiment Station}

VoL. 27

JULY, 1958

No. 13

\section{ON THE SOIL CHEMISTRY OF RADIO-STRONTIUM ${ }^{1}$}

\section{R. K. SCHULZ, ${ }^{2}$ ROY OVERSTREET, ${ }^{3}$ and K. L. BABCOCK ${ }^{4}$}

\section{INTRODUCTION}

A PHenomenon of major concern to present-day soil chemists is the contamination of agricultural lands with strontium 90 and its subsequent introduction into food chains as a result of absorption by crops. At the present time, the general problem is all the more serious because comparatively little is known of the soil chemistry of minute traces of strontium and no means are at hand for assessing the availability of a given level of soil strontium to plants.

Perhaps the most reliable information concerning the uptake by plants has been obtained by experiments with culture solutions. The preponderance of these experiments suggests that in uptake by plants from culture solutions, Sr behaves very similarly to Ca. Actually, the evidence suggests that most plants cannot distinguish between the two elements in absorption although certain differences in behavior appear when $\mathrm{Sr}$ and $\mathrm{Ca}$ are translocated within the plant (Martin, et al., 1957). ${ }^{5}$ Experiments with excised roots conducted in this laboratory showed that the dilution of radio-strontium in the culture solution with inactive $\mathrm{Sr}$ and $\mathrm{Ca}$ was about equally effective in reducing the uptake of the isotope (Overstreet, 1957).

It is thus reasonable to conclude that absorption of $\mathrm{Sr}$ from culture solutions is very closely tied to the $\mathrm{Ca}$ absorption. That is, when the $\mathrm{Sr}$ to $\mathrm{Ca}$ ratio in the culture solution is high, one can expect a corresponding high ratio within the plant. In line with this general idea, Comar et al. (1957) have introduced the term strontium-calcium observed ratio, OR. For the problem under consideration, as expressed below:

$$
\mathrm{OR} \text { plant-culture solution }=\frac{\frac{\mathrm{Sr}}{\mathrm{Ca}} \text { in plant }}{\frac{\mathrm{Sr}}{\mathrm{Ca}} \text { in culture solution }}
$$

\footnotetext{
${ }^{1}$ This paper is based on work performed under contract number AT-(11-1)-34 Project 23, with the U. S. Atomic Energy Commission. Submitted for publication April 11, 1958.

${ }^{2}$ Assistant Specialist in the Experiment Station, Berkeley.

${ }^{3}$ Professor of Soil Chemistry and Soil Chemist in the Experiment Station, Berkeley.

${ }^{4}$ Assistant Professor of Soil Chemistry and Assistant Soil Chemist in the Experiment Station, Berkeley.

"See "Literature Cited" for citations referred to in the text by author and date.
} 
Where there is no discrimination between $\mathrm{Sr}$ and $\mathrm{Ca}$ in absorption, the $\mathrm{OR}$ value will be equal to unity. Middleton, as reported by Martin et al. (1957), has determined the $O R$ values from culture solutions for some 10 plant species important in human diet or as sources of mineral nutrients in pastures. He found OR values ranging from 0.8 to 1.1. By and large, where gross uptake by the aerial parts of the plant is considered, it appears that satisfactory predictions concerning $\mathrm{Sr} 90$ absorption from culture solutions can be made assuming an $O R$ value of unity.

TABLE 1

SOIL SERIES AND TYPES USED FOR Sr 85 FIXATION STUDY

\begin{tabular}{|c|c|c|c|}
\hline Soil series, type & $\begin{array}{c}\mathrm{pH} \\
\text { Sat. paste }\end{array}$ & $\begin{array}{l}\text { Conductivity* } \\
\mathrm{m} . \mathrm{mho} / \mathrm{cm} .\end{array}$ & $\begin{array}{l}\text { Per cent } \\
\text { limet }\end{array}$ \\
\hline$\ldots \ldots \ldots \ldots \ldots \ldots \ldots \ldots \ldots \ldots \ldots \ldots \ldots$ & 5.6 & 0.86 & 0.0 \\
\hline Hanford v.f.s.l. & 7.7 & 0.46 & 0.0 \\
\hline Columbia v.f.s.l. $\ldots \ldots \ldots \ldots \ldots \ldots \ldots \ldots \ldots \ldots \ldots \ldots \ldots \ldots$ & 6.8 & 0.43 & 0.0 \\
\hline 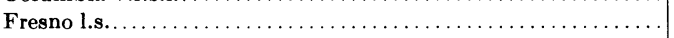 & 6.3 & 3.54 & 0.0 \\
\hline 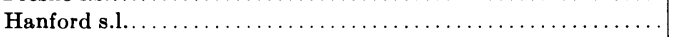 & 7.1 & 1.17 & 0.0 \\
\hline Yorkville $1 . .$. & 5.8 & 0.27 & 0.0 \\
\hline 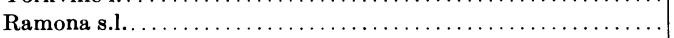 & 7.2 & 1.26 & 0.0 \\
\hline Tujunga v.f.s.l. & 6.1 & 1.74 & 0.0 \\
\hline 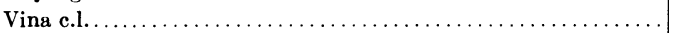 & 6.2 & 1.56 & 0.0 \\
\hline Yolo $1 . \ldots \ldots \ldots \ldots \ldots \ldots$ & 7.2 & 0.62 & 0.0 \\
\hline Ayar с $\ldots \ldots \ldots \ldots \ldots \ldots \ldots \ldots \ldots \ldots \ldots \ldots \ldots \ldots \ldots \ldots$ & 7.7 & 0.51 & 8.8 \\
\hline Kettleman c.l. $\ldots \ldots \ldots \ldots \ldots \ldots \ldots \ldots \ldots \ldots \ldots \ldots \ldots$ & 7.8 & 0.68 & 1.9 \\
\hline Meloland f.s............... & 8.3 & 2.69 & 4.2 \\
\hline Zaca c.................. & 7.4 & 0.74 & 7.7 \\
\hline 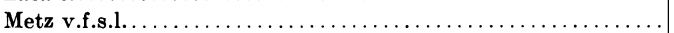 & 7.5 & 0.75 & 0.7 \\
\hline Superstition l.f.s. $\ldots \ldots \ldots \ldots \ldots \ldots \ldots \ldots \ldots \ldots \ldots \ldots \ldots \ldots \ldots$ & 8.2 & 0.33 & 0.53 \\
\hline 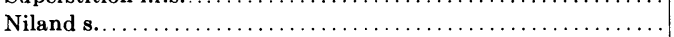 & 8.3 & 0.45 & 4.2 \\
\hline Cajon f.s.l. & 7.7 & 0.63 & 0.7 \\
\hline 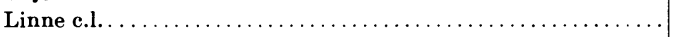 & 7.4 & 0.87 & 3.6 \\
\hline 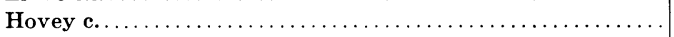 & 7.7 & 0.54 & 4.7 \\
\hline 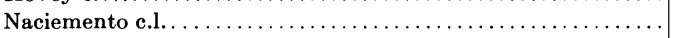 & 7.6 & 0.38 & 1.9 \\
\hline 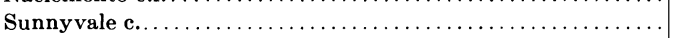 & 7.8 & 1.22 & 3.0 \\
\hline 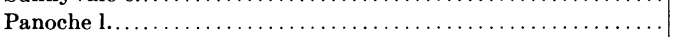 & 7.7 & 1.17 & 1.6 \\
\hline Tijeras & 7.4 & 114.00 & 7.2 \\
\hline 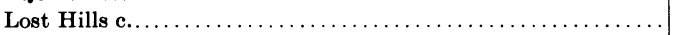 & 7.0 & 0.51 & 0.5 \\
\hline 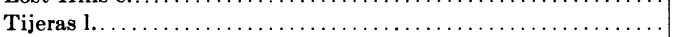 & 8.3 & 0.89 & 13.1 \\
\hline
\end{tabular}

* Saturation extract at $25^{\circ} \mathrm{C}$.

$\dagger$ Expressed as $\mathrm{CaCO}_{3}$.

Thus far, attempts to predict the distribution of $\mathrm{Sr} 90$ between plants and soils have yielded far less satisfactory results. For example, the work of Menzel (1954) and of Romney et al. (1956) with soils reveals OR values of much less than unity. A number of reasons for this are conceivable. In the first place, $\mathrm{Sr}$ and $\mathrm{Ca}$ in soils may exist largely in the adsorbed or exchangeable state and the adsorption energy of $\mathrm{Sr}$ may be considerably different from that of Ca. For this reason, the elements will not be equally available to plants as is presumably the case in culture solutions. Moreover, it is probable that the relative adsorption energies of $\mathrm{Sr}$ and $\mathrm{Ca}$ will vary considerably from soil to soil. In the second place, the $\mathrm{Sr}$ and Ca extracted from soil by means of the commonly employed methods such as extraction with HC1 or $\mathrm{NH}_{4} \mathrm{Ac}$, electrodialysis, and fusion analysis often bear little relationship to their relative availabilities to plants. For example, calcium present in the 
soil as $\mathrm{CaCO}_{3}$ may be only slightly available to crops, and yet such calcium is readily extracted from the soil with dilute acids or with $\mathrm{NH}_{4}$ Ac.

The question as to the manner in which added radio-strontium is retained in soil lies at the heart of the whole problem. Extremely insoluble compounds of strontium in which the element is unavailable to plants have been reported in some soils (Norrish, 1957). The work of Nishita et al. (1956) indicates that in many soils strontium is fixed in a nonexchangeable form. Klechkovsky and Tselschcheva (1957), however, did not find such fixation in three Russian soils studied.

In the present research, Sr 85 was added to 26 soils from California. Following this, efforts were made to determine the fraction of the added Sr that was in an exchangeable form. The presumption has been that under appropriate conditions, exchangeable $\mathrm{Sr}$ is available to plants.

TABLE 2

ANALYSES OF NONCALCAREOUS SOILS USED IN Sr 85 FIXATION STUDY

\begin{tabular}{|c|c|c|c|c|c|c|c|c|c|c|}
\hline \multirow{2}{*}{ Soil } & \multirow{2}{*}{$\begin{array}{c}\mathrm{pH} \\
1.5 \\
\text { susp. }\end{array}$} & \multicolumn{4}{|c|}{$\begin{array}{l}\text { Soluble cations } \\
\text { m.e. per } 100 \mathrm{gms}\end{array}$} & \multicolumn{4}{|c|}{$\begin{array}{l}\text { Exchangeable cations } \\
\text { m.e. per } 100 \text { gms }\end{array}$} & \multirow{2}{*}{$\begin{array}{c}\text { Exchange } \\
\text { capacity } \\
\text { m.e./ } \\
100 \text { gms } \\
\left(\mathrm{NH}_{4} \mathrm{Ac}\right)\end{array}$} \\
\hline & & $\mathrm{Ca}$ & $\mathbf{M g}$ & $\mathrm{Na}$ & $\mathrm{K}$ & $\mathrm{Ca}$ & $\mathrm{Mg}$ & $\mathrm{Na}$ & $\mathrm{K}$ & \\
\hline Aiken c.l.. & 5.8 & 0.00 & 0.00 & 0.00 & 0.00 & 9.12 & 3.24 & 0.08 & 0.70 & 17.40 \\
\hline Hanford v.f.s.l. & 7.9 & 0.37 & 0.09 & 0.07 & 0.05 & 15.3 & 2.90 & 0.38 & 0.60 & 12.2 \\
\hline Columbia v.f.s.l. & 6.6 & 0.14 & 0.07 & 0.05 & 0.06 & 13.5 & 3.70 & 0.83 & 0.15 & 13.9 \\
\hline Fresno l.s........ & 7.4 & 0.46 & 0.29 & 0.12 & 0.07 & 4.04 & 1.12 & 0.27 & 0.47 & 3.5 \\
\hline Hanford s.l.. & 7.2 & 0.15 & 0.08 & 0.14 & 0.03 & 7.68 & 2.20 & 0.14 & 0.27 & 6.8 \\
\hline Yorkville 1. . & 6.2 & 0.04 & 0.05 & 0.04 & 0.01 & 7.10 & 6.40 & 0.04 & 0.26 & 13.4 \\
\hline Ramona s.l.. & 7.3 & 0.17 & 0.10 & 0.12 & 0.00 & 6.04 & 1.91 & 0.23 & 0.19 & 6.50 \\
\hline Tujunga v.f.s.l... & 7.3 & 0.41 & 0.17 & 0.11 & 0.05 & 11.9 & 2.74 & 0.36 & 1.15 & 12.6 \\
\hline Vina c.l..... & 6.5 & 0.15 & 0.17 & 0.04 & 0.00 & 16.2 & 13.2 & 0.25 & 0.24 & 26.12 \\
\hline Yolo $1 . .$. & 7.5 & 0.04 & 0.09 & 0.07 & 0.02 & 8.72 & 11.3 & 0.88 & 0.83 & 17.5 \\
\hline
\end{tabular}

\section{EXPERIMENTS}

A number of experiments have been carried out in which soils contaminated with $\mathrm{Sr} 85$ were treated and leached with neutral $1 \mathrm{~N}$ ammonium acetate and $1 \mathrm{~N} \mathrm{CaCl}_{2}$. Ammonium acetate of this strength is commonly used in the determination of the exchangeable cations in soils since $\mathrm{NH}_{4}$ ion is not normally present. With calcareous soils the method leads to high results because alkaline earth carbonates are appreciably soluble in this reagent. Therefore $1 \mathrm{~N}$ $\mathrm{CaCl}_{2}$ was selected as an exchanging reagent because calcium carbonate is not soluble in this solution.

For the above studies, 26 soils from California were selected on the basis of their extent as mapped in soil surveys. They included representative soils over a wide range of chemical and mineralogical composition. Ten of the soils were noncalcareous; the $\mathrm{pH}$ of the saturated pastes varied from 5.8 to 7.9. Sixteen of the soils were calcareous and had a $\mathrm{CaCO}_{3}$ content ranging from 0.5 to 13.1 per cent. Two soil samples each of the Hanford and Tijeras series were included; these were selected from widely separated locations. A list of the soil series used, together with the $\mathrm{pH}$ 's of the saturated pastes, conductivity of the saturation extracts and lime content (expressed as per 
cent $\mathrm{CaCO}_{3}$ ), is presented in Table 1. Additional chemical data concerning the noncalcareous soils are given in Table 2.

The leaching experiments were carried out in the following manner. Twenty-five grams of air-dry soil (pulverized to pass a $2 \mathrm{~mm}$ screen) was weighed into a $250 \mathrm{ml}$ beaker and $50 \mathrm{ml}$ of a carrier-free solution containing approximately 10 microcuries of carrier-free $\mathrm{Sr} 85$ and $8 \times 10^{-4}$ m.e. of $\mathrm{HC1}$

TABLE 3

DATA SHOWING EFFICIENCY OF EXTRACTION OF SR 85 FROM SOILS BY LEACHING WITH $1 \mathrm{~N} \mathrm{NH}_{4} \mathrm{Ac}$ AND $1 \mathrm{~N} \mathrm{CaCl}_{2}$. SOILS WERE DRIED FOR ONE WEEK AT $50^{\circ} \mathrm{C}$ AND $110^{\circ} \mathrm{C}$ AFTER ADDITION OF Sr 85 AND PRIOR TO LEACHING. RESULTS ARE EXPRESSED AS PERCENTAGE OF ADDED Sr REMAINING IN SOIL AFTER LEACHING PROCEDURE

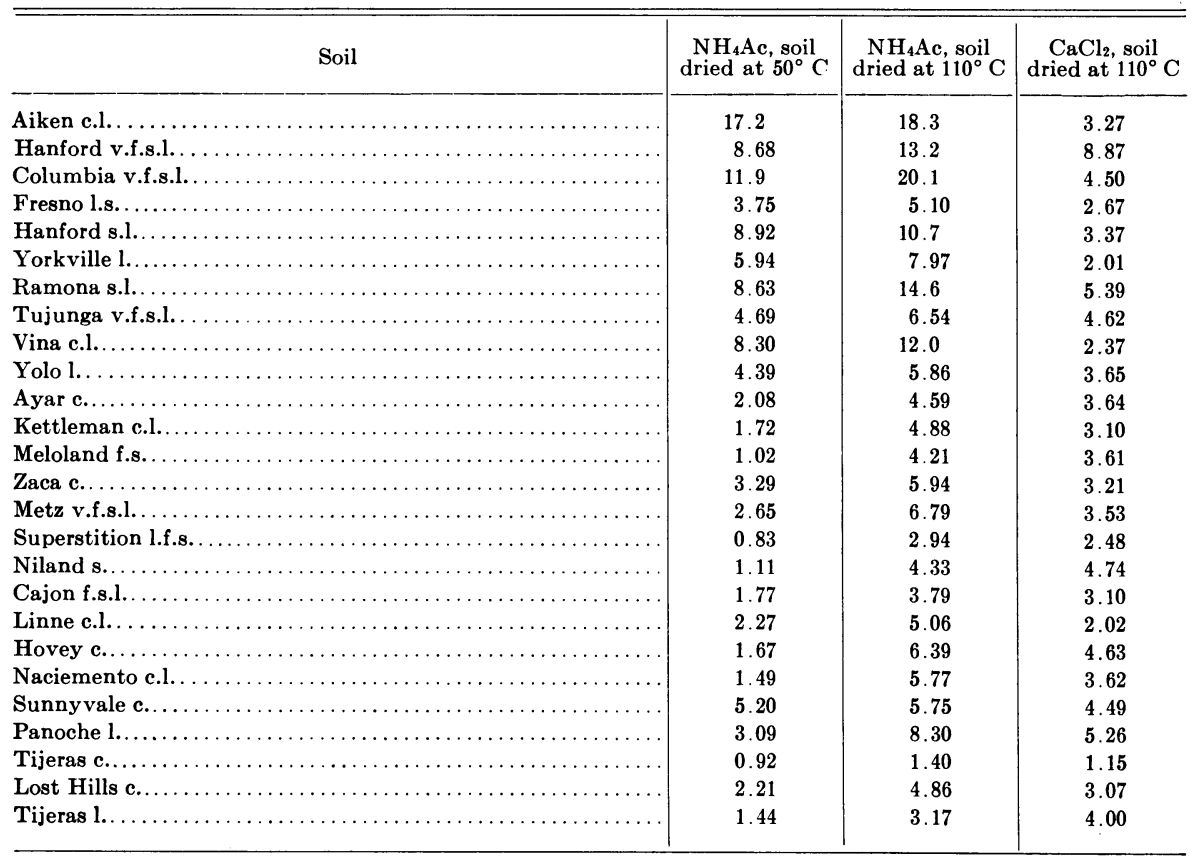

were added. The resulting suspension was stirred, evaporated down, and the residue was dried at either $50^{\circ} \mathrm{C}$ or $110^{\circ} \mathrm{C}$ for one week. Following this, $100 \mathrm{ml}$ of the $\mathrm{NH}_{4} \mathrm{Ac}$ or $\mathrm{CaCl}_{2}$ reagent were added and the mixture was heated on a steam bath for two hours during which time it was stirred occasionally. The suspension was then transferred to a Buchner funnel and leached with the exchanging reagent under gravity until $500 \mathrm{ml}$ of leachate were collected.

Radio-assays of both the leachates and extracted soils were made from the strontium gamma radiation only, using a scintillation counter with a sodium iodide crystal. For radio-assays of the solutions, $2 \mathrm{ml}$ aliquots were dried in cupped planchets of one inch diameter. The extracted soils were dried, ground, and mixed, and one gram samples were then assayed taking into account geometry and mass absorption. All experiments were performed at 
least in duplicate and in all cases the reproducibility was better than 5 per cent. The results of this line of study are presented in Table 3.

A second series of studies was carried out with the above soils in which a given weight of contaminated soil was repeatedly extracted with equal volumes of the $\mathrm{NH}_{4} \mathrm{Ac}$ reagent. It was thought that this type of study would reveal any fixation of the $\mathrm{Sr} 85$ in a form nonexchangeable with $\mathrm{NH}_{4}{ }^{+}$ion.

For the repeated extraction procedure, 5 grams of air-dry soil were weighed into a $50 \mathrm{ml}$ centrifuge tube and $2 \mathrm{ml}$ of carrier-free solution containing approximately 10 microcuries of $\mathrm{Sr} 85$ and $8 \times 10^{-4}$ m.e. of $\mathrm{HC} 1$ were added. The soil was dried at $50^{\circ} \mathrm{C}$ for seven days and then suspended in $25 \mathrm{ml}$ of neutral, normal ammonium acetate. After shaking for 10 minutes, the soil was centrifuged down and the supernatant liquid was decanted off. This extraction process was carried out 10 times with fresh portions of $1 \mathrm{~N}$ ammonium acetate. The soils and extracts were assayed for $\mathrm{Sr} 85$ as described above.

The percentages of added $\mathrm{Sr} 85$ remaining in the various soils after 10 extractions with $\mathrm{NH}_{4} \mathrm{Ac}$, are presented in Table 4 and compared with the corresponding $\left(50^{\circ} \mathrm{C}\right)$ percentages remaining after leaching with $\mathrm{NH}_{4} \mathrm{Ac}$.

The progress of radio-strontium removal upon successive extractions with ammonium acetate is shown graphically for nine of these soils in figures 1 , 2 , and 3 .

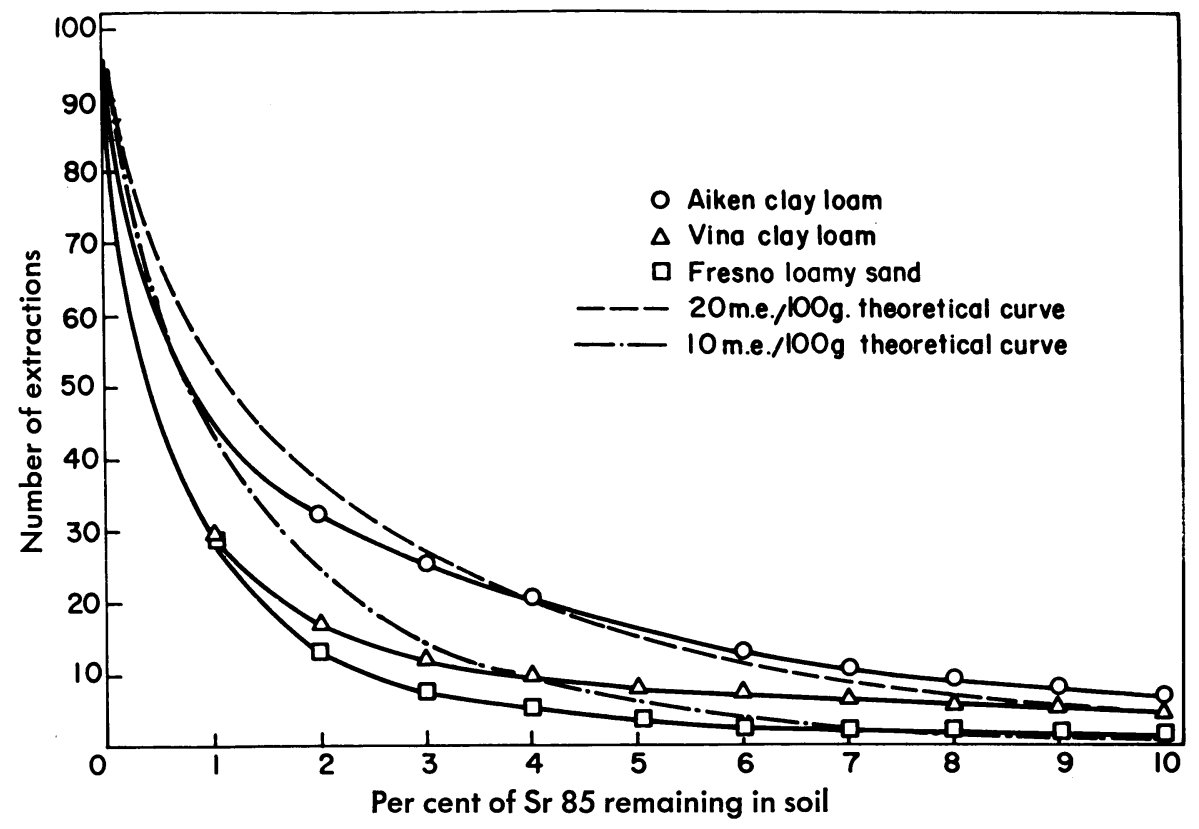

Fig. 1. Extraction of $\mathrm{Sr} 85$ from Aiken, Vina, and Fresno soils with $1 \mathrm{~N} \mathrm{NH} \mathrm{N}_{4} \mathrm{Ac}$ 


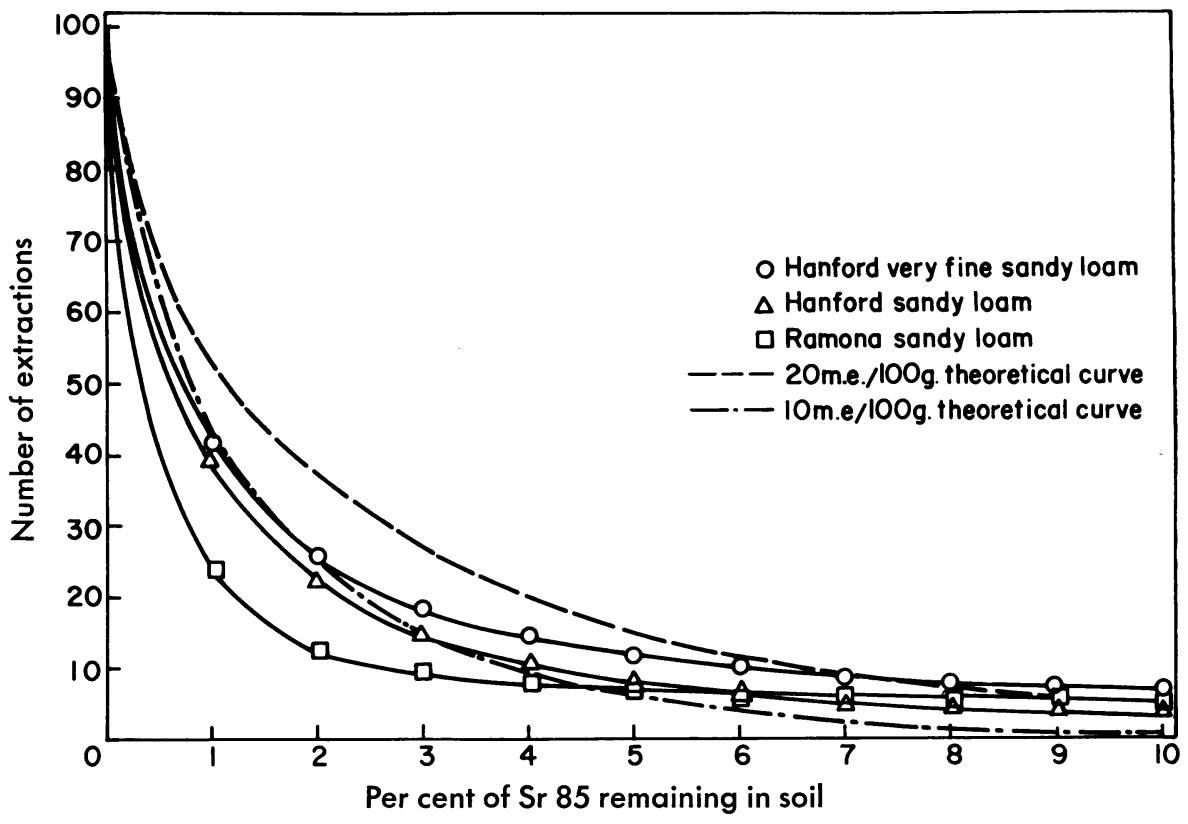

Fig. 2. Extraction of $\mathrm{Sr} 85$ from Hanford and Ramona soils with $1 \mathrm{~N}^{\mathrm{NH}_{4} \mathrm{Ac}}$

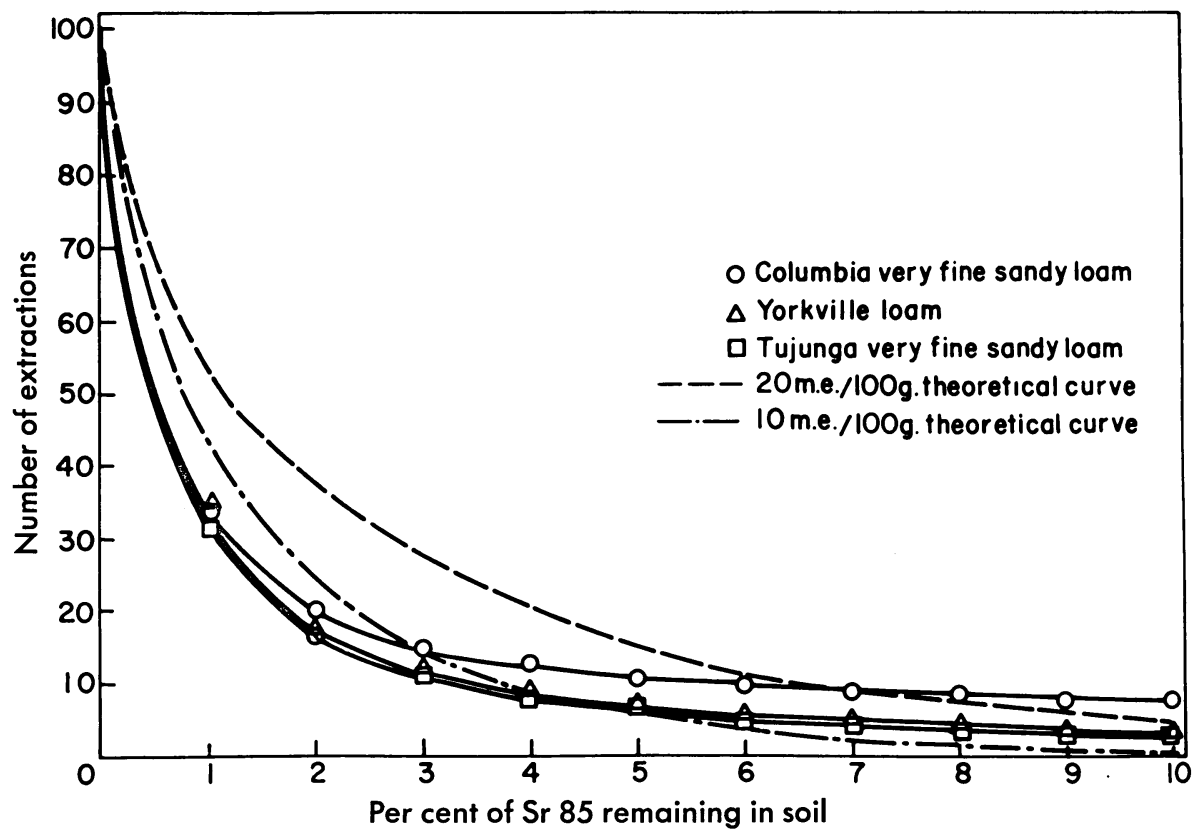

Fig. 3. Extraction of $\mathrm{Sr} 85$ from Columbia, Yorkville, and Tujunga soils with $1 \mathrm{~N} \mathrm{NH}_{4} \mathrm{Ac}$ 


\section{DISCUSSION AND CONCLUSIONS}

In general, the major fraction of the $\mathrm{Sr} 85$ added to the 26 Californian soils was extracted by the $\mathrm{NH}_{4} \mathrm{Ac}$ and $\mathrm{CaCl}_{2}$ leaching procedures adopted (see Table 3 ). This was true regardless of whether the soils had been dried at $50^{\circ}$ $\mathrm{C}$ or at $110^{\circ} \mathrm{C}$ prior to leaching.

Certain of the noncalcareous soils dried at $50^{\circ} \mathrm{C}$, namely, Aiken c.l., Han-

TABLE 4

PERCENTAGES OF ADDED Sr 85 REMAINING IN SOILS AFTER REPEATED EXTRACTION (10 EXTRACTIONS) WITH $1 \mathrm{~N} \mathrm{NH}_{4} \mathrm{Ac}$ AND AFTER CONTINUOUS LEACHING WITH $1 \mathrm{~N}$ $\mathrm{NH}_{4}$ Ac. ALL SOILS WERE DRIED AT $50^{\circ} \mathrm{C}$ FOR ONE WEEK AFTER ADDITION OF Sr 85 AND PRIOR TO TREATMENTS WI'TH $\mathrm{NH}_{4} \mathrm{Ac}$

\begin{tabular}{|c|c|c|}
\hline Soil & $\begin{array}{c}\text { Extracted } 10 \\
\text { times with } \\
\text { 1N NH}{ }_{4} \mathrm{Ac}\end{array}$ & $\begin{array}{l}\text { Continuously } \\
\text { leached with } \\
1 \mathrm{~N} \mathrm{NH}{ }_{4} \mathrm{Ac}\end{array}$ \\
\hline Aiken c.l. & 7.20 & 17.2 \\
\hline Hanford v.f.s.l. . & 6.50 & 8.68 \\
\hline Columbia v.f.s.l.... & 7.40 & 11.9 \\
\hline 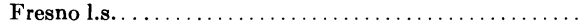 & 1.80 & 3.75 \\
\hline Hanford s.l............. & 3.30 & 8.92 \\
\hline Yorkville $1 . . . \ldots \ldots \ldots$ & 3.10 & 5.94 \\
\hline Ramona s.l......... & 5.40 & 8.63 \\
\hline Tujunga v.f.s.l. & 2.80 & 4.69 \\
\hline Vina c.l. ....... & 5.20 & 8.30 \\
\hline Yols $1 . . . . . \ldots \ldots \ldots$ & 2.50 & 4.39 \\
\hline Ayar c................ & 2.08 & 2.08 \\
\hline Kettleman c.l. . . & 2.11 & 1.72 \\
\hline Meloland f.s. $\ldots \ldots \ldots \ldots \ldots \ldots \ldots \ldots \ldots \ldots \ldots \ldots \ldots \ldots \ldots \ldots \ldots \ldots$ & 1.66 & 1.02 \\
\hline Zaca c. $\ldots \ldots \ldots \ldots \ldots \ldots \ldots \ldots \ldots \ldots \ldots \ldots \ldots \ldots \ldots$ & 2.35 & 3.29 \\
\hline Metz v.f.s.l $\ldots \ldots \ldots \ldots \ldots \ldots \ldots \ldots \ldots \ldots \ldots \ldots$ & 2.36 & 2.65 \\
\hline Superstition l.f.s. $\ldots \ldots \ldots \ldots \ldots \ldots \ldots \ldots \ldots \ldots \ldots$ & 0.99 & 0.83 \\
\hline Niland s............. & 1.54 & 1.11 \\
\hline 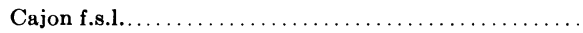 & 1.34 & 1.77 \\
\hline Linne c.l............ & 1.79 & 2.27 \\
\hline 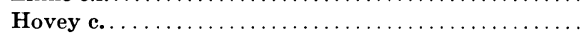 & 2.24 & 1.67 \\
\hline Naciemento c.l. $\ldots \ldots \ldots \ldots \ldots \ldots \ldots \ldots \ldots \ldots \ldots$ & 2.23 & 1.49 \\
\hline Sunnyvale c........ & 3.46 & 5.20 \\
\hline Panoche $1 . .$. & 3.47 & 3.09 \\
\hline Tijeras c.... & 1.17 & 0.92 \\
\hline Lost Hills c.. & 1.75 & 2.21 \\
\hline Tijeras $1 . \ldots \ldots \ldots \ldots$ & 2.26 & 1.44 \\
\hline
\end{tabular}

ford v.f.s.l., Columbia v.f.s.l., Hanford s.l., Ramona s.l., and Vina c.l., retained unexpected amounts of $\mathrm{Sr} 85$ against the leaching with $\mathrm{NH}_{4}$ Ac. Also, the effect appears to have been enhanced by drying at $110^{\circ} \mathrm{C}$. It is unlikely, however, that this is an actual fixation of the $\mathrm{Sr}$ in nonexchangeable form because the effect is not apparent when the soils are leached with $\mathrm{CaCl}_{2}$, even after drying at $110^{\circ} \mathrm{C}$. Moreover, considerably less $\mathrm{Sr} 85$ is retained by these soils when repeatedly extracted with $\mathrm{NH}_{4} \mathrm{Ac}$ (see Table 4 ).

The data of Table 4 indicate that the repeated $\mathrm{NH}_{4} \mathrm{Ac}$ extraction procedure adopted is generally more efficient than the $\mathrm{NH}_{4} \mathrm{Ac}$ leaching procedure. The graphical presentation of the repeated extraction data (figures 1, 2, and 3) 
reveals large differences between soils in the rate at which the Sr 85 is released in exchange for $\mathrm{NH}_{4}^{+}$.

According to Vanselow's equation given above, the saturation of the soil with $\mathrm{NH}_{4}^{+}$would not reach completion during the period of elevated temperature on the steam bath. Also, the subsequent leaching on a Buchner funnel possibly would not remove all of the remaining exchangeable ions owing to the existence of regions which are inaccessible, or only slowly accessible, to the leaching solution. In the repeated extraction procedure, however, the soil mass is shaken between each extraction, bringing all of the surface into contact with fresh solution.

It is reasonable to suppose that the $\mathrm{CaCl}_{2}$ leaching is more efficient because the soil becomes essentially $\mathrm{Ca}++$ saturated during the period of equilibration on the steam bath, and any subsequent channeling on the Buchner funnel is insignificant. There are apparently two reasons for this: in the first place, $\mathrm{Ca}++$ is a much stronger replacing agent than $\mathrm{NH}_{4}^{+}$, and in the second, the soils are initially high in exchangeable $\mathrm{Ca}++$.

The dotted theoretical curves in the figures emphasize that the rate of release of the Sr may depend markedly on the exchange capacity of the soil. The theoretical curves were calculated assuming that the applied $\mathrm{Sr}$ is exchangeable and that Vanselow's exchange equation applies (Vanselow, 1932); that is,

$$
\frac{m_{\mathrm{Sr}^{++}} \cdot N_{\mathrm{NH}_{+}}^{2}}{m_{\mathrm{NH}_{4}}^{2} \cdot N_{\mathrm{Sr}^{++}}^{+}}=K_{v} \cdot \frac{\left(\gamma_{\mathrm{NH}_{4}^{+}}\right)^{2}}{\gamma_{\mathrm{Sr}^{++}}}
$$

where $m$ is the solution molality, $N$ the mole fraction of the adsorbed ion, $K_{v}$ the exchange constant, and $\gamma$ the ionic activity coefficient in solution. For the calculations, the value of

$$
K_{v} \cdot \frac{\left(\gamma_{\mathrm{NH}_{4}}\right)^{2}}{\gamma_{\mathrm{Sr}^{++}}}
$$

was taken as $10^{-4}$. The curves were calculated for exchange capacities of 10 and 20 milliequivalents per 100 grams of soil.

The experimental and theoretical curves of figures 1 to 3 show further that complete removal of the added $\mathrm{Sr} 85$ is approached asymptotically as the number of extractions is increased. Moreover, they point up the danger that the selection of a limited extraction procedure may lead to erroneous values for the amount of $\mathrm{Sr}$ held in a nonexchangeable form. For the soils under study, it is clear from the figures that in no case has the slope of the extraction curve reached a value of zero even after the tenth extraction. Thus it cannot be assumed that any of the added $\mathrm{Sr} 85$ is retained in a nonexchangeable form.

The authors are led to conclude, on the basis of the evidence presented here, that essentially all of the $\mathrm{Sr} 85$ added to the 26 California soils was retained in an exchangeable or water soluble form. This appears to be the case whether the soil is calcareous or noncalcareous or whether the soil is dried at an elevated temperature after addition of the Sr. This conclusion, 
however, does not preclude the possibility of a long-term aging effect whereby the $\mathrm{Sr}$ isotope is slowly converted to a nonavailable form. If such an aging effect exists, it is probable that months or even years will be required before it becomes noticeable in the soils studied in this research.

The consequent conclusion that $\mathrm{Sr} 90$, added to soils by way of fallout, is probably retained in an exchangeable form and hence available to plants has important implications concerning the use of $\mathrm{OR}_{\text {plant-so11 }}$ values. That is, the generally observed inconstancy of such values must be due largely to variations in the relative adsorption energies of $\mathrm{Sr}$ and $\mathrm{Ca}$ from soil to soil. In other words, $\mathrm{OR}_{\mathrm{plant-so1}}$ values based on the ratio of exchangeable soil $\mathrm{Sr}$ to exchangeable soil $\mathrm{Ca}$ will not assume a particular figure and thus cannot be used to supply information concerning the uptake of $\mathrm{Sr} 90$ by plants.

A solution to the problem is conceivable. Where the free electrolytic concentration of the soil is low, the $\frac{\mathrm{Sr}}{\mathrm{Ca}}$ ratio in a water extract of the soil is to a good approximation a measure of the activity ratio of $\mathrm{Sr}$ and $\mathrm{Ca}$ in the soil. It is also entirely possible that uptake of Sr from soil may depend on this activity ratio rather than on the ratio of exchangeable soil Sr to exchangeable soil Ca. If this should prove to be the case, the calculation of the value

$$
\mathrm{OR}_{\text {plant-soil }}=\frac{\frac{\mathrm{Sr} 90}{\mathrm{Ca}} \text { in plant }}{\frac{\mathrm{Sr} 90}{\mathrm{Ca}} \text { in water extract of soil }}
$$

would be appropriate and could be used in assessing the Sr 90 availability in soils. Experiments bearing on this question are presently being conducted in this laboratory. 


\section{LITERATURE CITED}

Comar, C. L., R. Scott Russell, and R. H. Wasserman

1957. Strontium-calcium movement from soil to man. Science $126: 485-92$.

KLeCHkovsky, V. M., and G. N. TselishCHEVA

1957. On the behavior of fission products in soil. Academy of Sciences of the U.S.S.R.

(Translated from Russian and published by the U. S. Atomic Energy Commission.)

Martin, R. P., P. Newbould, and R. ScotT Russell

1957. Discrimination between strontium and ealcium in plants and soils. International Conference on Radioisotopes in Scientific Research, Paris. UNESCO/NS/RIC/175. MENZEL, R. G.

1954. Competitive uptake of $\mathrm{K}, \mathrm{Rb}$, Co and $\mathrm{Ca}, \mathrm{Sr}, \mathrm{Ba}$ from soils. Soil Science 77:419-25. Nishita, K., et al.

1956. Fixation and extractability of fission products contaminating various soils and clays. Soil Science 81:317-26.

Norrish, $\mathrm{K}$.

1957. Some phosphate minerals of soils. Second Australian Conference in Soil Science, Melbourne. Vol. 1, Part 1.

OVERSTREET, RoY

1957. Decontamination of soils containing salt and radioactive elements. Progress Report of Contract AT(11-1)-34 Project 23 with the U. S. Atomic Energy Commission.

RoMney, E. M., et al.

1956. Effects of calcium and strontium on plant uptake of Sr 90 and stable strontium from nutrient solutions and soils. Report No. UCLA 374 of Contract No. AT-04-1GEN-12 with the U. S. Atomic Energy Commission.

VANSELow, A. P.

1932. Equilibria of the base-exchange reactions of bentonites, permutites, soil colloids and zeolites. Soil Science 33:95-113. 
The journal Hilgardia is published at irregular intervals in volumes of about 600 pages. The number of issues per volume varies.

Subscriptions are not sold. The periodical is sent as published only to libraries, or to institutions in foreign countries having publications to offer in exchange.

You may obtain a single copy of any issue free, as long as the supply lasts; please request by volume and issue number from:
Agricultural Publications
Room 22, Giannini Hall
University of California
Berkeley 4 , California

The limit to nonresidents of California is 10 separate issues on a single order. $A$ list of the issues still available will be sent on request. 


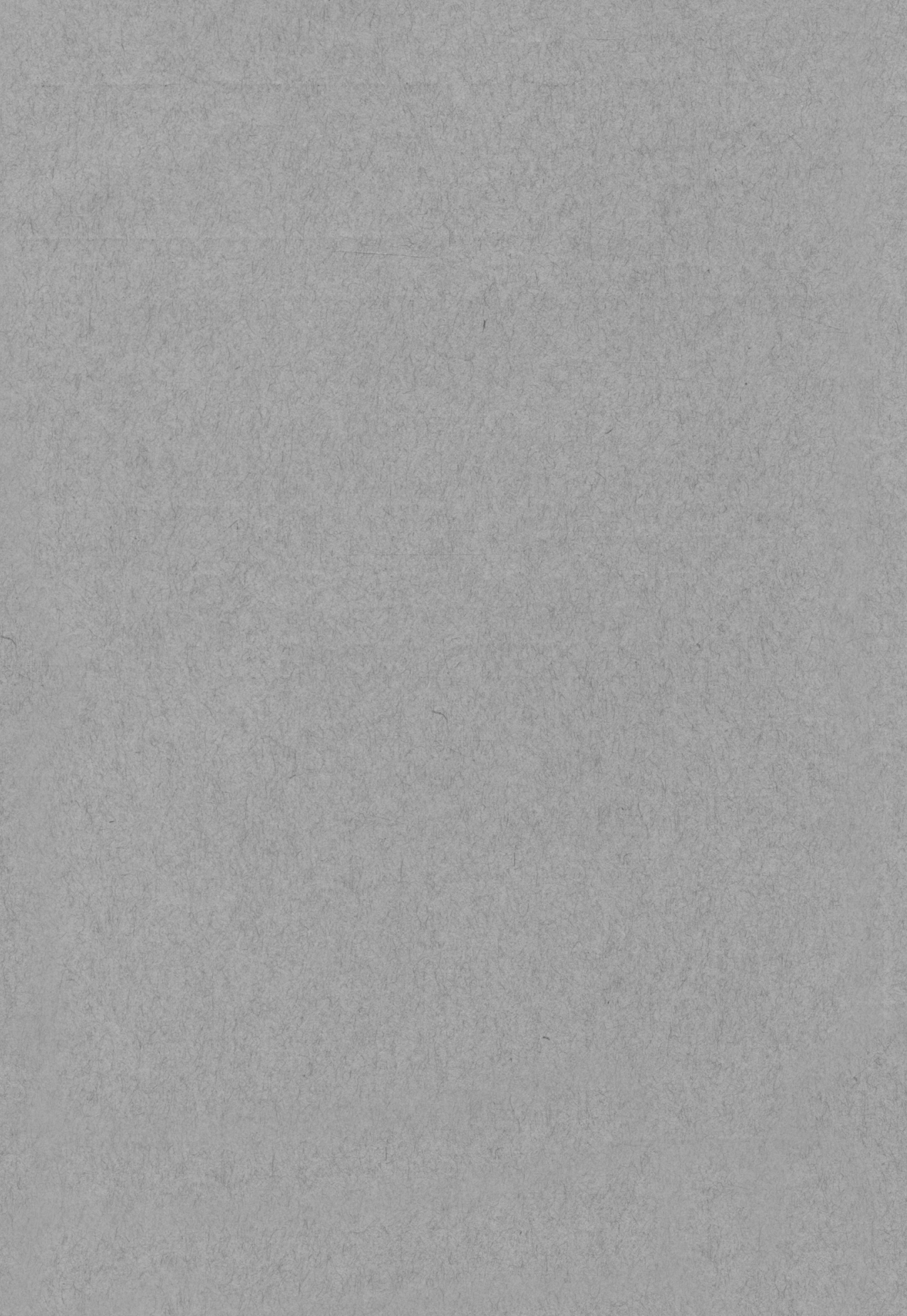

